\title{
Penerapan Think Pair Share dalam Menulis Teks Deskripsi di Sekolah Menengah Pertama (SMP)
}

\author{
Veni Nurpadillah ${ }^{\mathrm{a}, 1}$, Tato Nuryanto ${ }^{\mathrm{a}, 2}$ \\ ${ }^{a}$ IAIN Syekh Nurjati Cirebon, Indonesia \\ ${ }^{1}$ veninurpadillah@syekhnurjati.ac.id; ${ }^{2}$ tatonuryanto28@gmail.com \\ A B S T R A C T \\ Article history: \\ Received: $22-04-2020$ \\ Reviced: 10-06-2020 \\ Accepted:24-06-2020

\begin{abstract}
Writing description text is a language skill that students must master. This is in line with the implementation of the 2013 curriculum for seventh grade junior high school. Based on the 2013 curriculum it is stated that the learning objectives in writing description text by adjusting core competencies and basic competencies. Core competencies are trying, processing and serving, according to the material being studied. The core competencies are divided into several basic competencies including understanding verbal and written descriptive texts. The results of this study show, (1) The application of Think Pair Share learning models is effectively used in writing description texts in grade VII students. (2) Writing description text using the Think Pair Share model can increase student activity. The research method used was a quasi-experimental
\end{abstract} \\ method and the population of VII grade students of SMPN 1 \\ Ciawigebang.
}

Keywords:

Think Pair Share Model Writing

Description Text

\begin{abstract}
Menulis teks deskripsi merupakan keterampilan bahasa yang harus dikuasai siswa. Hal tersebut sejalan dengan penerapan kurikulum 2013 SMP kelas VII.Berdasarkan Kurikulum 2013 disebutkan, bahwa tujuan pembelajaran dalam kegiatan menulis teks deskripsi dengan menyesuaikan kompetensi inti dan kompetensi dasar. Kompetensi inti yaitu mencoba, mengolah dan menyaji, sesuai materi yang dipelajari. Kompetensi inti tersebut terbagi dalam beberapa kompetensi dasar diantaranya yaitu memahami teks deskriptif secara lisan maupun tulisan. Hasil penelitian ini menunjukan, (1) Penerapan model pembelajaran Think Pair Share efektif digunakan dalam menulis teks deskripsi pada siswa kelas VII. (2) Menulis teks deskripsi dengan menggunakan model Think Pair Share dapat membuat keaktifan siswa meningkat. Metode penelitian yang digunakan adalah metode eksperimen semu dan populasinya siswa kelas VII SMPN 1 Ciawigebang.
\end{abstract}

Copyright $\odot 2020$ Institut Agama Islam Negeri Syekh Nurjati Cirebon. All rights reserved.

\section{PENDAHULUAN}

Penelitian ini dilakukan karena hasil observasi menunjukkan bahwa kemampuan menulis siswa masih rendah. Hal ini karena kurangnya motivasi dan kegiatan yang memacu siswa untuk langsung praktik menulis, khususnya dalam menulis teks deskripsi. Kegiatan menulis ini perlu ditekankan pada siswa yang masih berada di kelas bawah, untuk membiasakan siswa dalam menulis. Oleh karena itu dibutuhkan penerapan model pembelajaran yang memotivasi siswa untuk melakukan keterampilan menulis. Model Think Pair Share dirasa mampu menarik perhatian siswa dalam melakukan kegiatan, khususnya dalam mengamati sebuah objek, sehingga dapat membantu siswa dalam berpikir dan menggambarkan hasil pengamatannya itu melalui tulisan berbentuk teks deskripsi. Penelitian dengan 
menerapkan model ini memang sudah banyak dilakukan, namun jarang diterapkan dalam kegiatan keterampilan menulis khususnya menulis teks deskripsi.

Menulis adalah keterampilan berbahasa yang mempunyai hubungan dengan proses berpikir serta berekspresi dalam bentuk tulisan (Khairullah, Syambasril, \& Wartiningsih, 2019). Selain itu, menulis dapat membuat seseorang berpikir kreatif, inisiatif, serta meningkatkan kecerdasan secara akademis (Wardiani \& Mulyaningsih, 2015). Wiyanto (2004) menyatakan bahwa banyak orang sudah menyadari pentingnya menulis, tetapi kesulitan dalam mempraktikannya. Keterampilan menulis dan membaca yang dimiliki setiap manusia hanya bisa diperoleh dan dikembangkan dengan menguasai konsep teoretis beserta latihan (Tarigan, 2009).

Menulis adalah keterampilan yang prosesnya berlangsung terus-menerus, (Agustina dkk, 2004). Dewi (2011) menyatakan bahwa terdapat permasalahan dalam pembelajaran menulis di sekolah. Pembelajaran menulis dinilai merupakan kegiatan yang sulit dilakukan karena siswa tidak terbiasa menuangkan isi pikiran dalam bentuk tulisan. Rukniyati (2014) menyatakan bahwa pembelajaran bahasa dan sastra di sekolah masih monoton, serta faktor minat membaca dan menulis siswa sangat rendah. Padahal keterampilan menulis merupakan keterampilan dasar namun masih banyak peserta didik kesulitan dalam mengungkapkan bahasanya dalam bentuk tulisan (Purwantiningsih, 2013).

Pembelajaran menulis teks deskripsi merupakan salah satu keterampilan bidang bahasa yang harus dikuasai siswa. Hal tersebut sejalan dengan penerapan kurikulum 2013 yang terdapat pada silabus SMP kelas VII mengenai pembelajaran menulis teks deskripsi. Kurikulum 2013 menyebutkan bahwa cara belajar harus sesuai dengan tujuan pembelajaran yang hendak dicapai. Pembelajaran menulis teks deskripsi mengacu pada kompetensi inti, yaitu mencoba, mengolah dan menyaji, sesuai materi yang dipelajari disekolah. Kompetensi inti tersebut terbagi dalam beberapa kompetensi dasar di antaranya memahami teks deskriptif secara lisan maupun tulisan. Dalam hal ini, penelitian difokuskan pada kompetensi dasar (4.1) yaitu menyusun teks deskriptif sesuai karakteristik teks yang akan dibuat, baik secara lisan maupun tulisan.

Semi (2007) mengungkapkan bahwa teks deskripsi merupakan tulisan yang bertujuan untuk memberikan rincian mengenai objek sehingga dapat berpengaruh pada emosi dan menciptakan imajinasi pembaca. Tompkins (dalam Zainurrahman, 2013) menjelaskan bahwa teks deskripsi adalah tulisan yang seolah-olah menggambarkan sebuah gambar dengan menggunakan kata-kata. Dengan kata, tulisan deskripsi digunakan untuk menggambarkan sebuah objek, dengan mengandalkan kosakata. Kosakata dalam teks deskripsi bertujuan memperluas pengalaman pembaca dengan cara melukiskan hakikat objek (Nurudin, 2010). Teks deskripsi mempunyai tujuan untuk memperluas pengetahuan dengan cara melukiskan objek. Maksudnya adalah dalam menulis deskripsi membutuhkan keahlian tertentu karena tulisan itu harus bisa memberikan gambaran sebuah objek agar para pembaca bisa merasakan layaknya melihat sendiri objek yang dilukiskan. Selain itu pula, kemampuan seseorang penulis harus mampu melihat secara detail objek yang dijadikan bahan tulisannya akan membuat tulisan itu terkesan hidup dan menarik. 
Think Pair Share (Berpikir Berpasangan Berbagi) awal mula dikembangkan oleh Lyman. Trianto (2011) menyatakan bahwa model pembelajaran Think Pair Share adalah cara yang efektif dalam membuat variasi diskusi di dalam kelas. Prosedur yang digunakan dalam model ini dapat memberi siswa lebih banyak waktu untuk berpikir merespon, serta saling membantu. Tembang (2017) menyatakan bahwa Think Pair Share dapat dijadikan model pilihan untuk meningkatkan motivasi belajar siswa dan hasil belajar siswa. Slavin (2005) mengemukakan bahwa model pembelajaran Think Pair Share adalah metode sederhana, tetapi sangat bermanfaat dalam kegiatan pembelajaran. Model pembelajaran ini dapat membantu siswa untuk memecahkan suatu permasalahan dengan cara berdiskusi. Karena caranya yang cukup sederhana, model pembelajaran ini dapat diterapkan di dalam kelas rendah. Model pembelajaran Think Pair Share efektif digunakan dalam kegiatan pembelajaran (Ariyanti, 2014).

Barkley (2012) mengungkapkan bahwa Think Pair Share adalah teknik yang efektif, terutama sebagai pemanasan melakukan diskusi kelas. Think Pair Share (TPS) adalah model kooperatif yang dirancang dalam bentuk diskusi dan mampu meningkatkan kemampuan berpikir dan keterampilan berkomunikasi siswa di kelas (Azlina, 2010). Lie (2004) juga mengungkapkan bahwa Think Pair Share mempunyai keunggulan dan kelemahan. Keunggulan pada model pembelajaran Think Pair Share, yaitu meningkatkan kemampuan siswa untuk mengingat informasi. Sementara kelemahan, yaitu siswa pasif karena dengan berpasangan suasana kelas akan ramai dan akan mengganggu siswa lain. Dewi (2015) menyatakan bahwa penggunaan Think Pair Share berpengaruh signifikan terhadap pemahaman konsep siswa.

Adapun langkah-langkah pada pembelajaran menulis teks deskripsi dengan menggunakan model Think Pair Share sebagai berikut.

1. Terlebih dahulu guru menjelaskan pengertian dan ciri teks deskripsi. Setelah itu, guru menjelaskan model Think Pair Share. Berikut ini pengertian dan ciri teks deskripsi yang dijelaskan kepada siswa: a) deskripsi harus lebih menggambarkan perincian mengenai objek yang diamati, b) teks ini bersifat memberikan sensitivitas dan membentuk imajinasi pembaca, c) dapat disampaikan dengan diksi yang menarik dengan pilihan kata yang mudah dipahami, dan d) pemaparan objek harus dijelaskan lebih mendalam agar penggambarannya seolah dapat dirasakan dan objek yang dipilih biasanya berupa benda, alam, warna, dan manusia.

2. Setelah siswa memahami tentang teks deskripsi, guru meminta kepada seluruh siswa mengamati gambar yang telah disediakan guru di depan kelas, untuk mengamati taman sekolah yang ada tepat di halaman sekolah.

3. Ketika seluruh siswa sudah berada di taman sekolah, guru memberikan waktu kepada siswa untuk mengamati apa saja yang dilihat dan dirasakan di taman sekolah.

4. Seluruh siswa diberikan kesempatan untuk berpikir dan menulis rincian-rincian apa saja yang dilihat, dipegang, dan dirasakan di taman sekolah.

5. Setelah seluruh siswa mengamati dan berpikir, guru memerintahkan kepada siswa untuk kembali lagi ke dalam kelas. 
6. Setelah seluruh siswa sudah kembali ke dalam kelas, siswa diminta untuk saling berpasangan dengan teman sebelahnya, dan saling bertukar pikiran atas apa yang didapat dari hasil mengamati taman sekolah. Guru memberi waktu sekitar lima menit untuk berpasangan dan bertukar pikiran.

7. Masing-masing pasangan diberikan kesempatan untuk menyampaikan atau berbagi hasil diskusi kepada guru dan seluruh siswa di depan kelas.

8. Setelah seluruh pasangan menyampaikan hasil diskusi, seluruh siswa diberikan tugas individu untuk membuat teks deskripsi yang terinspirasi dari taman sekolah.

\section{METODE}

Penelitian ini menggunakan metode penelitian eksperimen semu. Metode penelitian semu digunakan karena eksperimen semu ini memiliki desain kelompok kontrol. Penelitian ini menggunakan dua kelas, yaitu kelas eskperimen dan kelas kontrol. Untuk mengetahui akibat dari perlakuan yang diterapkan pada kelas eksperimen dan sebagai pembandingnya adalah kelas kontrol. Perlakuan yang diterapkan di kelas eksperimen, yaitu pembelajaran dengan menggunakan model Think Pair Share (TPS), sedangkan kelas kontrol tidak mendapatkan perlakuan.

Metode penelitian yang digunakan dalam penelitian ini adalah eksperimen kuasi. Pola ini digunakan untuk mengetahui pengaruh dari suatu perlakuan terhadap subjek penelitian. Populasi pada penelitian ini adalah siswa kelas VII semester satu di SMP Negeri 1 Ciawigebang yang terdiri atas 8 kelas. Sampelnya adalah berdasarkan kemampuan siswa khususnya dalam pembelajaran menulis teks deskripsi yang memiliki nilai rata-rata hampir sama setelah dilakukan tes atau ulangan pada masing-masing kelas, yaitu kelas VII C sebagai kelas eksperimen dan kelas VII D sebagai kelas kontrol. Jumlah siswa pada masing-masing kelas adalah 36 orang.

Instrumen yang digunakan dalam penelitian ini adalah tes dan observasi. Tes dilakukan dua kali, yakni awal dan akhir. Kedua jenis data ini digunakan untuk mengetahui kemampuan siswa terhadap penulisan teks deskripsi yang dibuktikan lewat nilai yang dihasilkan siswa. Observasi digunakan untuk mengamati siswa dan guru dalam proses belajar. Data dalam penelitian ini meliputi data hasil observasi aktivitas siswa dalam pembelajaran, data hasil pembelajaran, serta data hasil pembelajaran yang berupa nilai hasil tes kelompok eksperimen dan kelompok kontrol. Teknik pengolahan data yang akan dilakukan, meliputi: hasil tes berupa angka atau nilai diolah mengunakan statistika dan hasil observasi yang dianalisis menggunakan uraian deskripsi. Data hasil tes kemudian diolah dengan menggunakan uji statistika uji $\mathrm{t}$ ( $t$-test).

\section{HASIL DAN PEMBAHASAN}

\section{a. Analisis Hasil Tes di Kelas Eksperimen}

Berdasarkan hasil tes awal dan tes akhir perhitungan skor perolehan siswa dengan dibagi skor maksimal dan dikalikan dengan skor ideal akhirnya diperoleh nilai siswa dalam pembelajaran menulis teks deskripsi pada siswa kela VII C (kelas eksperimen) dideskripsikan sebagai berikut. 


\section{Indonesian Language Education and Literature \\ e-ISSN: 2502-2261 \\ http://www.syekhnurjati.ac.id/jurnal/index.php/jeill/ \\ Vol. 5, No. 2, Juli 2020, 237 - 248}

Berdasarkan hasil tes awal kelas eksperimen, jumlah nilai keseluruhan yang diperoleh adalah 2036 dengan rata-rata 56,55\%. Skor tes awal ini menunjukan hasil yang kurang memuaskan. Adapun rincian selengkapnya disajikan dalam gambar 1 .

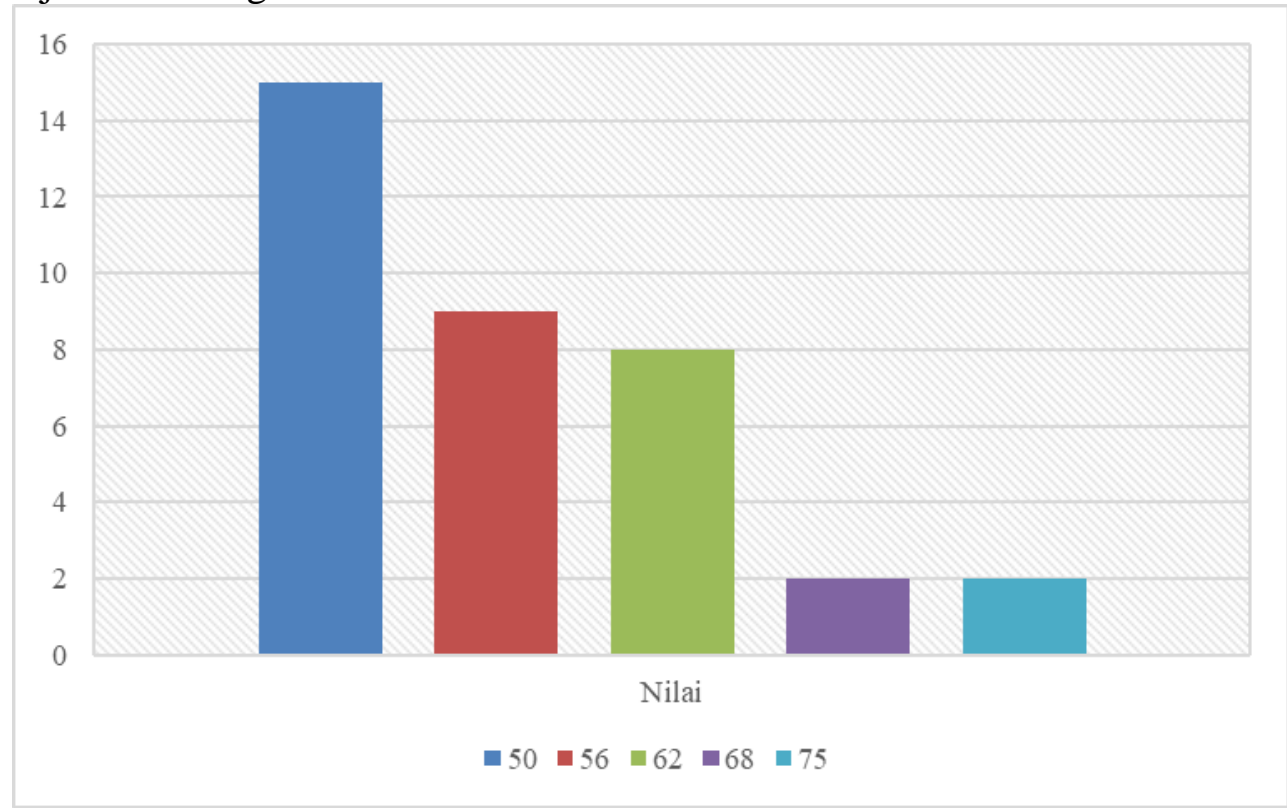

Gambar 1. Hasil Tes Awal Kelas Eksperimen

Gambar 1 dapat diinterpretasikan bahwa tes awal pada kelas eksperimen kegiatan menulis siswa masih rendah. Hal tersebut terbukti dari nilai rata-rata yang didapat kurang dari KKM. Hal tersebut dikarenakan kurangnya minat siswa untuk melakukan kegiatan menulis. Oleh karena itu, perlu dilakukan perlakukan atau diterapkannya model pembelajaran yang dapat memacu minat siswa dalam melakukan kegiatan keterampilan menulis teks deskripsi.

Setelah dilakukan tes pertama selanjutnya diberikan perlakuan terhadap kelas yang diberikan perlakuan berupa proses pengajaran dengan menerapkan model TPS. Setelah perlakuan diberikan, lalu dilakukan tes akhir pada kelas eksperimen dengan tujuan untuk mengetahui hasil tulisan siswa setelah diberi perlakuan. Hasil tes menunjukkan bahwa skor tes akhir lebih besar dari skor tes awal. Skor tes akhir mencapai 2838 dengan rata-rata 78,83. Adapun data selengkapnya disajikan pada gambar 2 . 


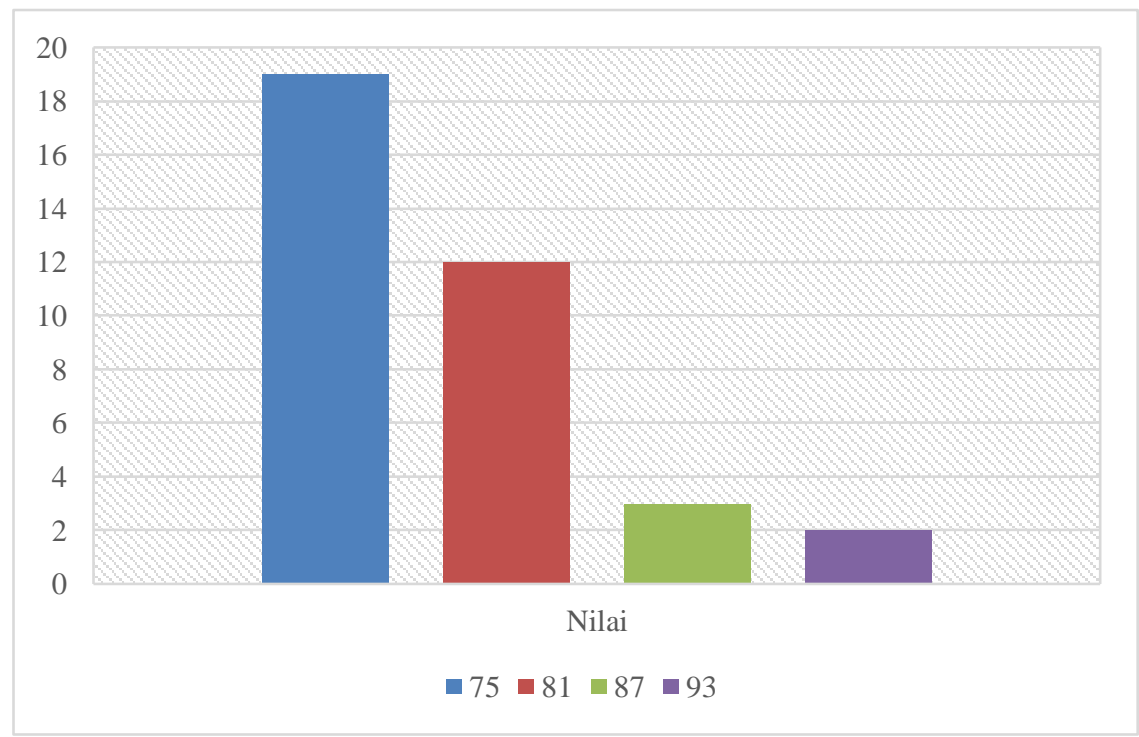

Gambar 2. Hasil Tes Akhir Kelas Eksperimen

Berdasarkan gambar 2 dapat diketahui hasil tes awal kurang memuaskan, tetapi setelah diberikan perlakuan dengan menggunakan model pembelajaran tersebut maka tes akhir siswa mendapatkan hasil yang memuaskan. Hal ini membuktikan bahwa pembelajaran menulis teks deskripsi dengan menggunakan model Think Pair Share lebih efektif.

\section{b. Analisis Hasil Tes di Kelas Kontrol}

Berdasarkan hasil tes awal dan tes akhir perhitungan skor perolehan siswa dibagi skor maksimal dan dikalikan dengan skor ideal diperoleh nilai siswa dalam pembelajaran menulis teks deskripsi pada siswa kelas VII D (kelas kontrol) dideskripsikan sebagai berikut. Berdasarkan hasil tes awal kelas kontrol, jumlah nilai keseluruhan yang diperoleh adalah 2001 dengan rata-rata 55,58\% Skor tes awal ini menunjukkan hasil yang kurang memuaskan. Adapun data selengkapnya disajikan dalam gambar 3. Selanjutnya skor tes akhir mencapai 2673 dengan rata-rata 74,25\%. Adapun data selengkapnya disajikan dalam gambar 4.

Instrumen tes penelitian dilakukan adalah tes pertama dan tes terakhir untuk mengetahui kemampuan menulis teks deskripsi yang telah dibuat oleh siswa. Berdasarkan hasil tes di kelas yang diberi perlakuan (eksperimen) dan di kelas yang tidak diberi perlakuan (kontrol), dapat disimpulkan hasil tes di kelas yang telah diberi perlakuan lebih efekif karena nilai rata-rata tes akhir di kelas tersebut lebih besar dibandingkan dengan nilai rata-rata tes akhir di kelas kontrol.

Berdasarkan lembar observasi aktivitas siswa, dari 10 penilaian aspek keaktifan siswa pada kelas eksperimen dapat dikatakan baik, karena kelas eksperimen mendapatkan nilai rata-rata yaitu 7,05 dengan persentase 19,44\% . Dari 10 aspek, aspek nomor 8 mendapat respon terbanyak dengan persentase $88 \%$ yaitu siswa mengerjakan tugas menulis teks deskripsi dengan baik. 
Indonesian Language Education and Literature e-ISSN: 2502-2261

http://www.syekhnurjati.ac.id/jurnal/index.php/jeill/

Vol. 5, No. 2, Juli 2020, 237 - 248

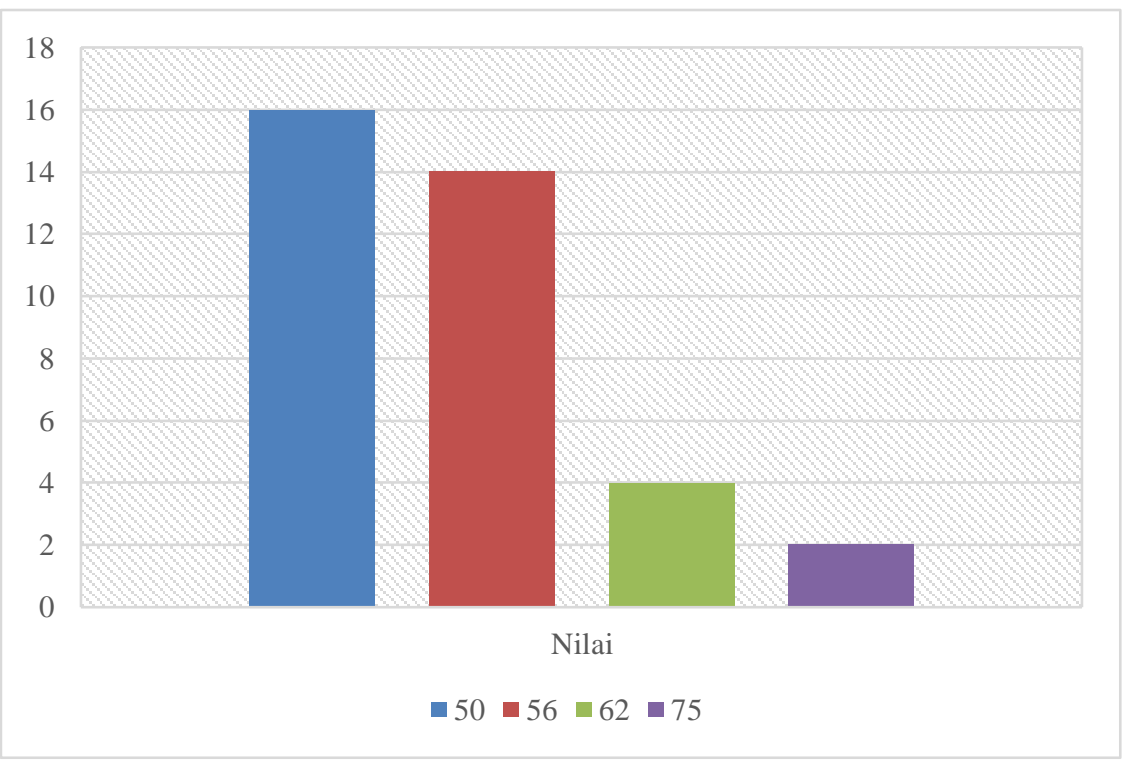

Gambar 3. Hasil Tes Awal Kelas Kontrol

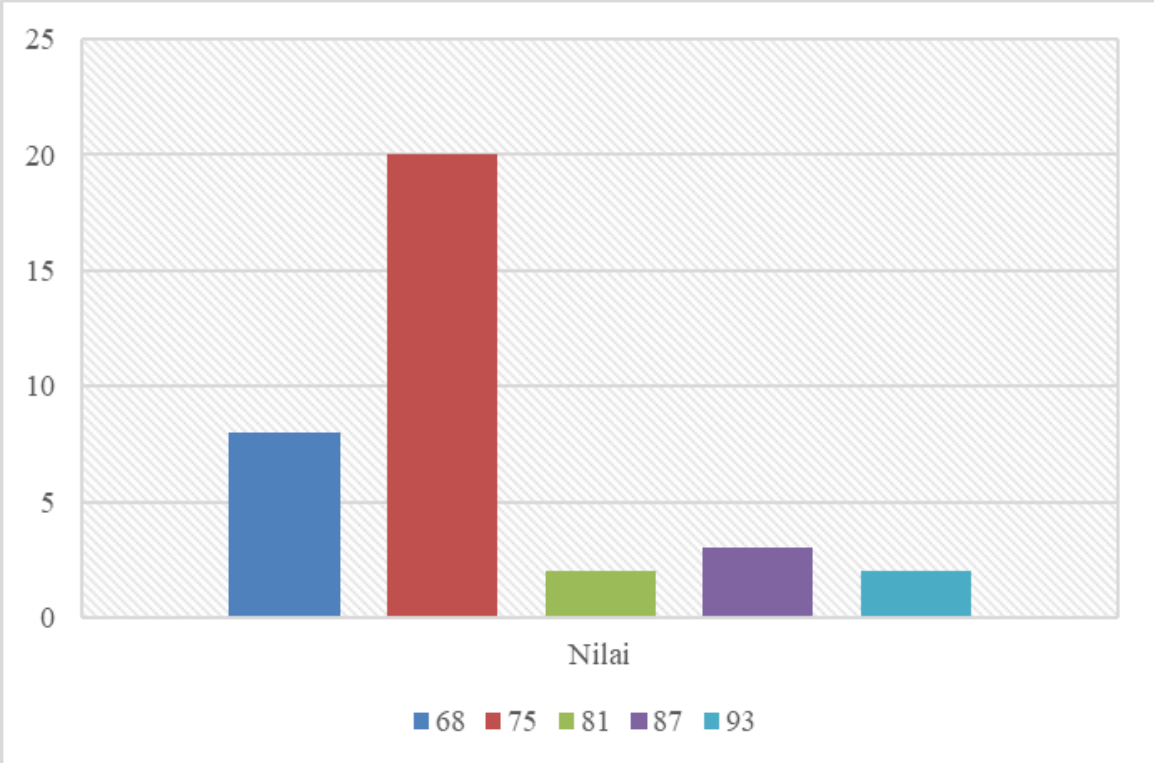

Gambar 4. Hasil Tes Akhir Kelas Kontrol 


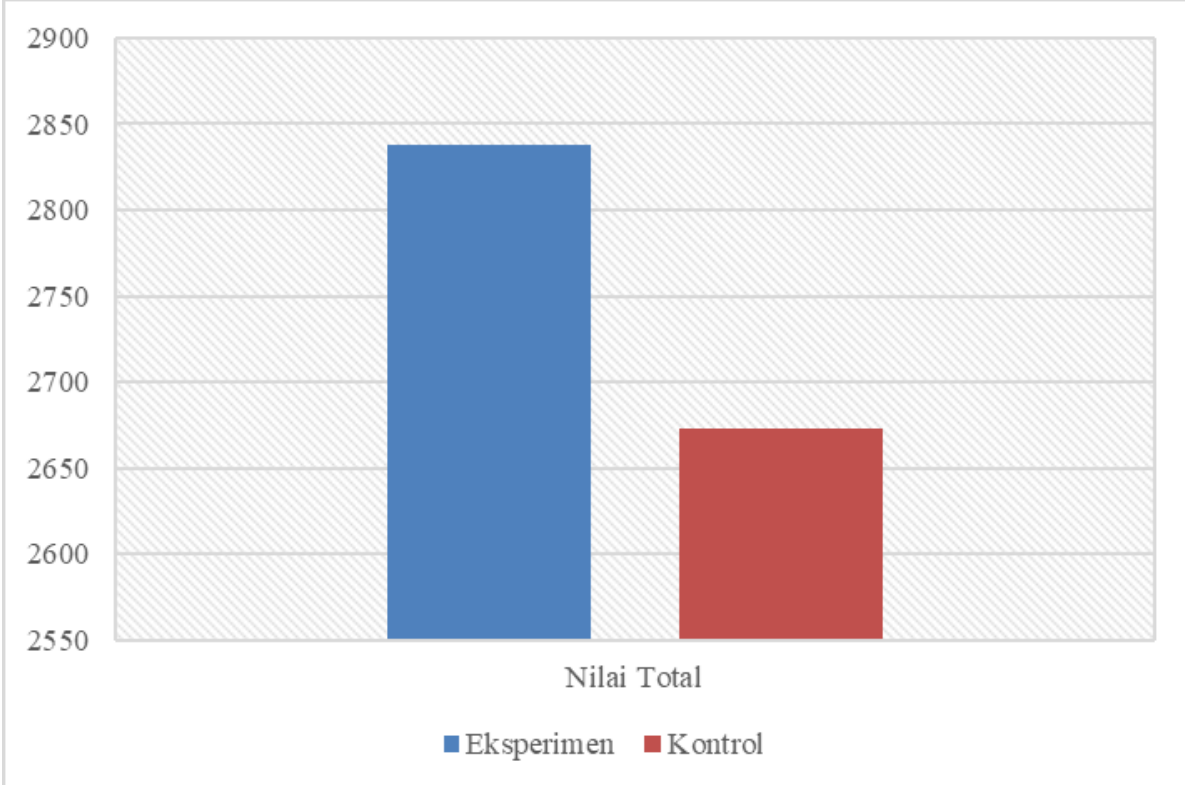

Gambar 5. Hasil Tes Akhir Kelas Eksperimen dan Kontrol

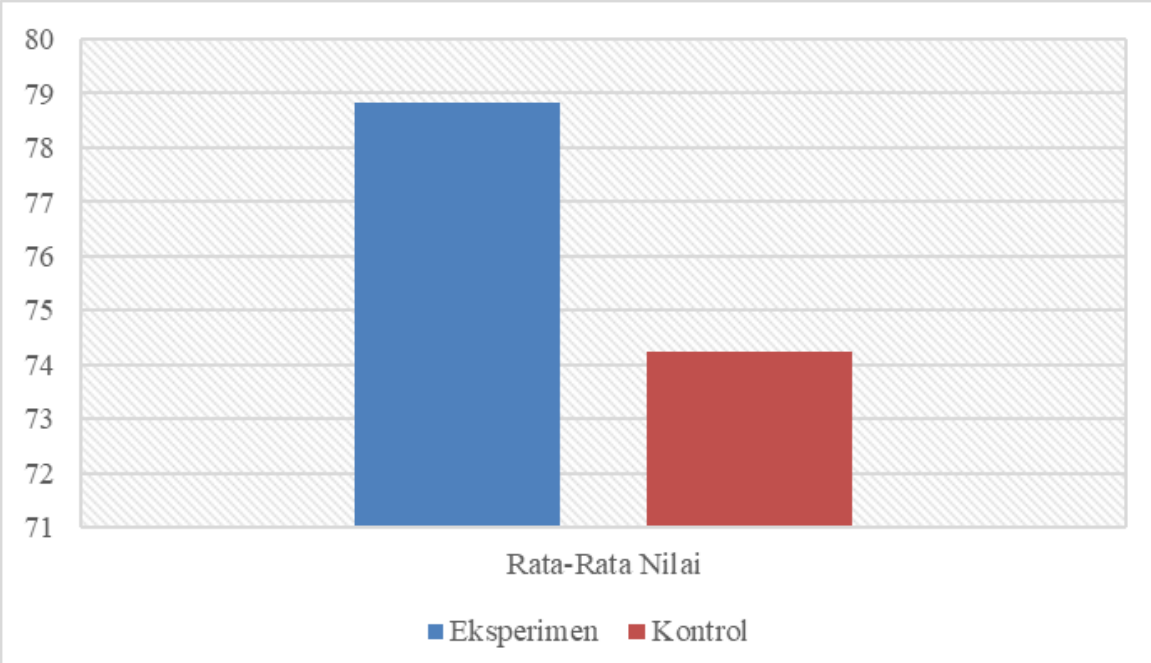

Gambar 6. Rata-Rata Hasil Tes Akhir Kelas Eksperimen dan Kontrol 


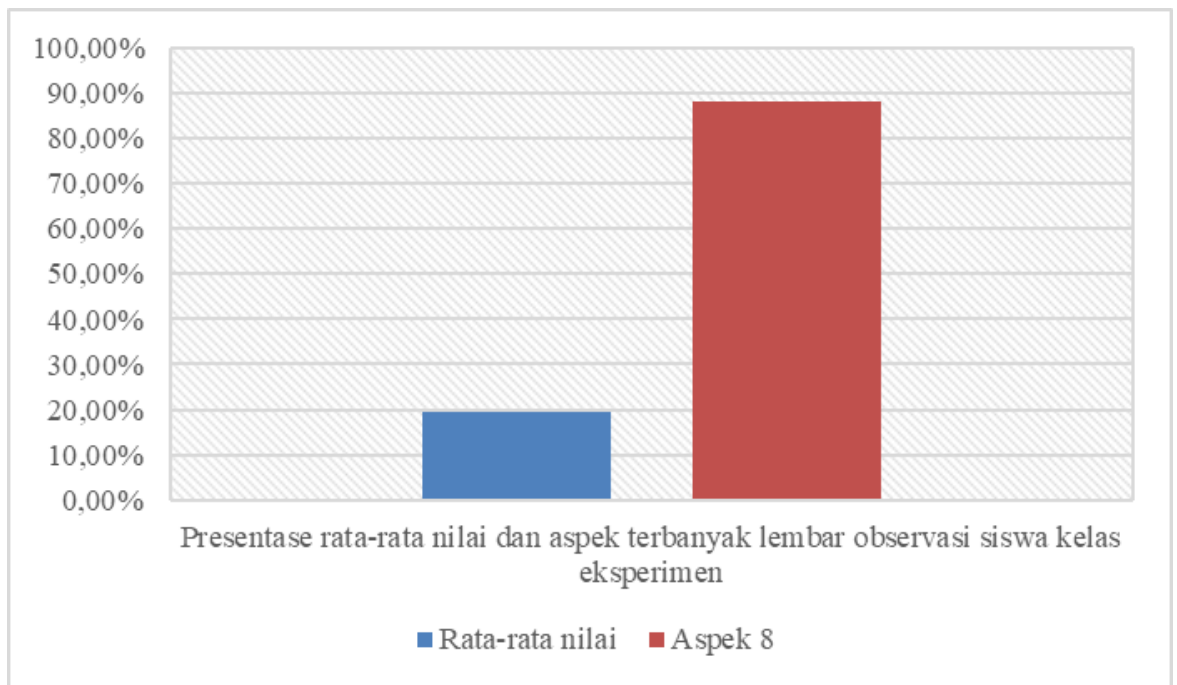

\section{Gambar 7. Rata-Rata pada Lembar Observasi di Kelas Eksperimen}

Berdasarkan lembar observasi aktivitas siswa, keaktifan siswa pada kelas kontrol dapat dikatakan baik, karena mendapatkan nilai rata-rata yaitu 6,01 dengan persentase $16,80 \%$, namun jika dibandingkan dengan kelas eksperimen, kelas ini keaktifan siswanya kurang baik karena kelas eksperimen mendapatkan nilai rata-rata yaitu 7,05 dengan persentase 19,44\%. Dari 10 aspek, aspek nomor 7 mendapat respon terbanyak dengan persentase $80 \%$ yaitu siswa dapat mengerjakan tugas menulis teks deskripsi dengan sungguh-sungguh.

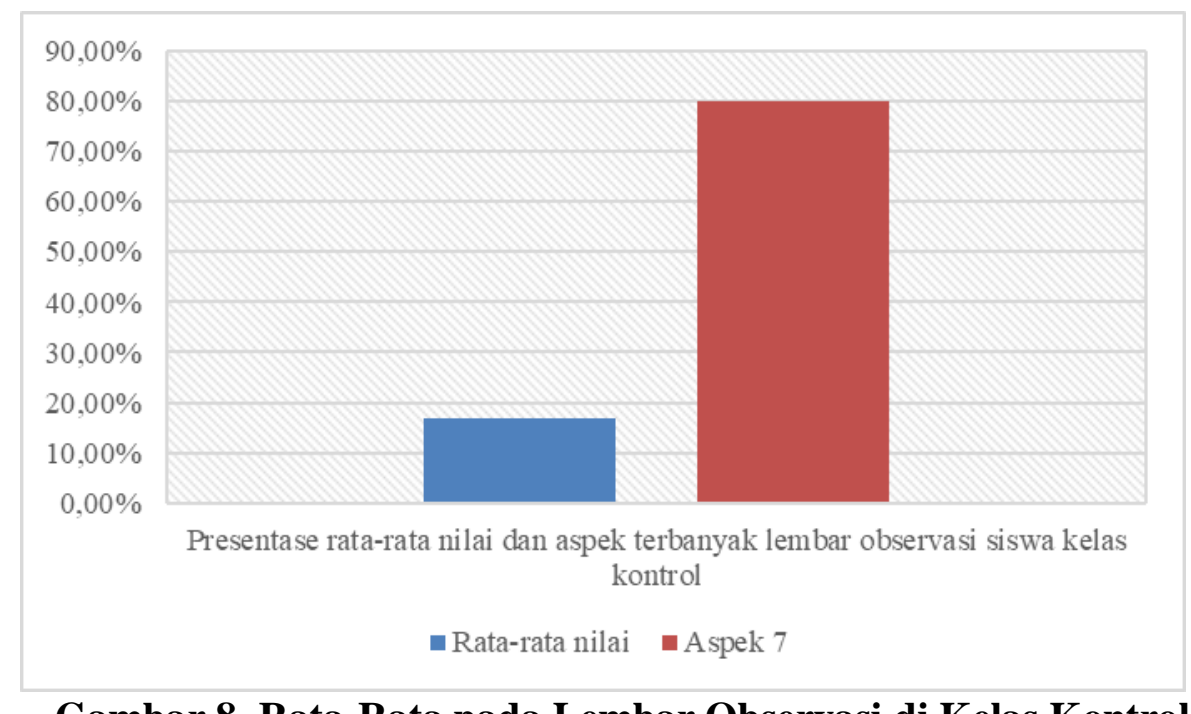

Gambar 8. Rata-Rata pada Lembar Observasi di Kelas Kontrol

\section{c. Pengolahan Data Hasil Tes}

Data penelitian dari hasil tes awal dan akhir menulis teks deskripsi pada siswa kelas VII C sebagai kelas eksperimen dan siswa kelas VII D sebagai kelas kontrol akan dianalisis dan diolah dengan menggunakan uji statistik (uji $t$ ). 
Tabel 1.

Data Hasil Tes Awal dan Tes Akhir Pembelajaran Menulis Teks Deskripsi

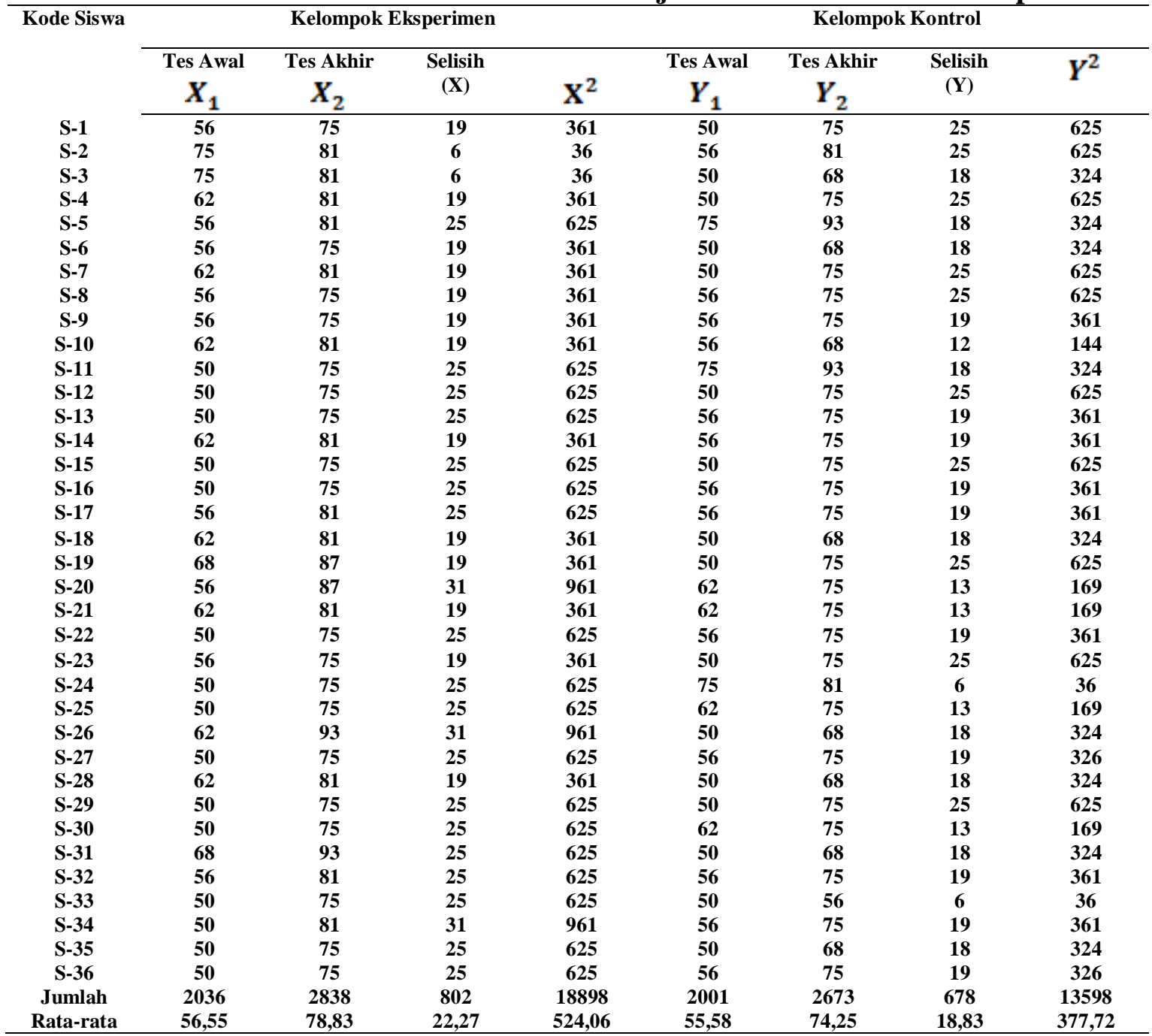

Berdasarkan penghitungan diperoleh $t$ hitung sebesar 3,75. Selanjutnya mencari $\mathrm{t}_{\text {tabel }}$ dengan menentukan derajat kebebasan (dk) 70 dengan taraf signifikan 5\%. Dengan demikian, untuk menguji nilai tabel digunakan interpolasi sebagai berikut.

$$
\begin{aligned}
& t_{\text {tabel }}=t\left[1-{ }_{2}^{1} a\right](d b) \\
& t_{\text {tabel }}=t\left[1-\frac{1}{2}(0,05)\right](70) \\
& t_{\text {tabel }}=t[1-0,025](70) \\
& t_{\text {tabel }}=t[0,975](70) \\
& t_{\text {tabel }}=1,99
\end{aligned}
$$


Berdasarkan hasil pengolahan data di atas, dapat di simpulkan bahwa nilai $t$ hitung lebih besar dari nilai $t$ hitung, yaitu 3,75 dan $t$ tabel 1,99.

\section{d. Pengolahan Data Hasil Observasi Aktivitas Siswa}

Hasil tes menunjukkan bahwa pemahaman belajar aktif siswa di kelas eksperimen mengalami peningkatan pada saat pembelajaran berlangsung dengan menggunakan model TPS. Hal tersebut dapat dilihat dengan hasil pengolahan instrument tes dan observasi aktivitas siswa. Rata-rata hasil tes awal sebesar 56,55\% Dan tes akhir sebesar 78,83\% maka ini terdapat peningkatan hasil belajar siswa sesudah diterapkan model tersebut dalam pembelajaran menulis teks deskripsi kelas VII.

Hasil rata-rata kelas kontrol tes awal dan tes akhir, dapat dilihat dari rata-rata tes awal sebesar 55,58\% dan rata-rata tes akhir sebesar 74,25\%. Hal ini membuktikan terdapat perbedaan kelas yang menggunakan model berpikir berpasangan berbagi dan yang tidak menggunakan model berpikir berpasangan berbagi dalam pembelajaran menulis cerita pendek pada siswa kelas VII SMP Negeri 1 Ciawigebang.

Berdasarkan pengolahan data hasil tes dan observasi aktivitas di atas, maka dapat diketahui penerapan model pembelajaran Think Pair Share efektif digunakan pada materi menulis teks deskripsi di kelas VII SMPN 1 Ciawigebang. Hal ini terbukti dari tes akhir pada kelas yang diberi perlakuan diperoleh nilai rata-rata sebesar 78,83, sedangkan pada kelas kontrol diperoleh nilai rata-rata 74,25. Hal ini membuktikan nilai rata-rata kelas eksperimen lebih baik daripada kelas kontrol. Dari hasil uji t juga, dengan ini terbukti bahwa kelas eksperimen lebih besar dari kelas kontrol atau $t_{\text {hitung }}=3,75$ dan $\mathrm{t}_{\text {tabel }}=1,99$, maka dengan taraf signifikan $5 \%$ dengan ini dapat dikatakan $\mathrm{H}_{0}$ ditolak atau dengan kata lain hipotesis kerja $\left(\mathrm{H}_{\mathrm{i}}\right)$ diterima atau dengan kata lain modelnya dinyatakan efektif.

\section{SIMPULAN}

Berdasarkan analisis dapat disimpulkan bahwa keefektifan penerapan Think Pair Share dalam menulis teks deskripsi pada siswa kelas VII SMPN 1 Ciawigebang dapat dikatakan efektif. Aktivitas siswa dalam materi teks deskripsi dengan menggunakan model Think Pair Share di kelas VII SMPN 1 Ciawigebang dapat dikatakan aktif. Siswa merasa terbantu dengan adanya model tersebut dengan demikian, model ini sangat berpengaruh dalam membantu siswa di dalam menulis teks deskripsi. Hal itu terbukti dari hasil tes observasi pada kelas eksperimen mendapatkan rata-rata 7,05 dengan persentase $19,44 \%$.

\section{DAFTAR PUSTAKA}

Agustina, H. dkk. (2004). Materi Pelatihan Terintegrasi Bahasa Inggris. Jakarta: Depdiknas.

Arikunto, S. (2002). Prosedur Penelitian. Jakarta: Rineka Cipta.

Ariyanti, A. (2014). Keefektifan Model Think Pair Share Dalam Pembelajaran Nilai Moral Pada Kumpulan Dongeng Bawang Merah \& Bawang Putih Karya Tira Ikranegara Untuk Siswa Kelas VII SMPN 3 Kaliwungu. IKIP PGRI Semarang.

Azlina, N. A. N. (2010). CETLs Supporting Collaborative Activities Among Studentsand Teachers Through the Use of Think-Pair-Share Techniques. IJCSI 
International Journal of Computer Science Issues, 7(5):18-29. Tersedia di http://IJCSI.org [diakses3-2-2019].

Barkley. (2012). Collaborative Learning Techniques. Bandung: Nusa media.

Dewi, C. (2015). Penerapan Model Pembelajaran Kooperatif Tipe Think Pair Share untuk Meningkatkan Pemahaman Konsep Masalah Sosial IPS pada Siswa Sekolah Dasar. Premiere Educandum: Jurnal Pendidikan Dasar dan Pembelajaran, 5(2), 155-167. http://doi.org/10.25273/pe.v5i02.280

Dewi, K. S. (2011). Efektivitas Model Pembelajaran Think Pair Share Dalam Meningkatkan Kemampuan Menulis Paragraf Deskripsi Siswa Kelas X SMA Negeri Pematang. Universitas Negeri Medan.

Khairullah, Syambasril, \& Wartiningsih, A. (2019). Pembelajaran Menulis Teks Eksplanasi Pada Siswa Kelas XI SMAS Mujahidin Pontianak Tahun Ajaran 2018/2019. Jurnal Pendidikan dan Pembelajaran Khatulistiwa, 8(3), 1 - 11.

Lie, A. (2004). Cooperative Learning. Jakarta: PT. Grasindo.

Nurudin. (2010). Dasar-dasar Penulisan. Malang: UMM Press.

Purwantiningsih, E. (2013). Peningkatan Keterampilan Menulis Deskripsi Melalui Pendekatan Kontekstual Pada Siswa SD Negeri 2 Dlingo Boyolali. Universitas Sebelah Maret Srakarta.

Rukniyati. (2014). Keefektivan Metode Think Pair Share Berorientasi Multikultur Dalam Pembelajaran Membaca Kreatif. Universitas Pendidikan Indonesia.

Semi, M. A. (2007). Menulis Efektif. Padang: Angkasa Raya.

Slavin, R. E. (2005). Cooperative Learning. Bandung: Nusa Media.

Tarigan, D. (2009). Membina Keterampilan Menulis Paragraf. Bandung: Angkasa.

Tembang, Y. (2017). Peningkatan Motivasi dan Hasil Belajar Melalui Model Pembelajaran Think Pair Share Berbantuan Media Gambar di Sekolah Dasar. Jurnal Pendidikan: Teori, Penelitian, dan Pengembangan, 2(6), 812-817.

Trianto. (2011). Mendesain Model Pembelajaran Inovatif-Progresif. Jakarta: Kencana Prenada Media Group.

Wardiani, R. \& Mulyaningsih, I. (2015). Kemampuan Menulis Deskripsi (Studi Kasus di Pondok Pesantren Nuurusshiddiiq, Cirebon. Indonesian Language Education and Literature, 1(1), 1-16. doi: 10.24235/ileal.v1i1.36

Wiyanto. A. (2004). Terampil Menulis Paragraf. Jakarta: Grasindo.

Zainurrahman. (2013). Menulis Dari Teori Hingga Praktek. Bandung: Alfa Beta. 